\title{
RELASI MASYARAKAT DAN PERUSAHAAN SARI BUMI KUSUMA (SBK) DALAM PENGELOLAAN hUTAN DI HULU SUNGAI KATINGAN, KALIMANTAN TENGAH
}

\section{the RELATION BETWEEN LOCAL PEOPLE AND PRIVATE SECTOR (SARI BUMI KUSUMA) IN FOREST MANAGEMENT IN KATINGAN RIVER UPSTREAM, CENTRAL KALIMANTAN}

\author{
Mohammad Fathi Royyani ${ }^{1}$, Abdul Sukur ${ }^{2}$, dan Oscar Efendy ${ }^{1}$ \\ 1. Pusat Penelitian Biologi-Lembaga Ilmu Pengetahuan Indonesia \\ 2. Universitas Islam Negeri Gunung Djati, Bandung \\ moha036@lipi.go.id
}

\begin{abstract}
Abstrak
Artikel ini bertujuan untuk menjelaskan relasi antara masyarakat dan perusahaan kehutanan yang memiliki izin konsesi di Kalimantan Tengah. Terdapat masyarakat yang sudah lama tinggal di dalam kawasan konsesi tersebut. Diantara bentuk relasi antara kedua pihak adalah adanya kesepakatan bahwa swasta memberikan pelayanan sosial kepada masyarakat, selain sebagai bentuk tanggung jawab sosial juga sebagai ruang baru bagi swasta untuk berelasi dengan masyarakat. Dengan menggunakan konsep-kritis tentang negara, artikel ini berusaha menjelaskan cara perusahaan berperan sebagai negara pada satu sisi sedangkan di sisi lain tetap berorientasi keuntungan. Melalui pembahasan mengenai program-program yang diberikan, artikel ini berargumen bahwa peran-peran swasta dalam memberdayakan dan membangun masyarakat adalah bagian dari sistem produksi.
\end{abstract}

Kata kunci: Hutan, Transformasi Masyarakat, Marjinal, Pemberdayaan, Swasta.

\section{Abstract}

This paper aims to discuss the relation between local peoples and private sector who has forest concession in Central Kalimantan. There are local peoples living for years in the concession area. Onetype of interaction between those two parties is private sector should empower and develop local people. This commitment is a 'new space' for private sector to relate with local people. Using critical state theories, I will explain how private sector act like a state in one side and maintain the profit oriented side on the other side. Through discussion about empowering programs, I argue that private sector roles in empowering and developing local people are part of their production system.

Keywords: Forest, Marginalized Society, State, Empowering, Private Sector.

\section{Pendahuluan}

Artikel ini bertujuan untuk membahas relasi antara swasta dan masyarakat lokal dalam mengelola sumber daya alam yang dilakukan secara bersama karena kawasan hutan adat milik masyarakat juga masuk dalam area konsesi milik satu perusahaan swasta. Kajian ini penting dilakukan mengingat kajian-kajian sebelumnya seringkali membahas persoalan konflik antara masyarakat dan negara atau masyarakat dan swasta dalam perebutan dan pengelolaan sumber daya alam atau kehutanan (Peluso, 1993, 2006; Li, 2002; Edmunds dan Wollenberg, 2003). Bahkan, kajian-kajian dengan sudut pandang masyarakat melihat peran masyarakat sebatas pada gerakan-gerakan perlawanan masyarakat lokal terhadap pengelolaan yang dilakukan oleh negara, swasta atau orang di luar masyarakat (Ghee \& Gomes, 1993; Ellen, 2002; Peluso, 2006; Maring, 2010).

Belum banyak kajian yang melihat relasi antara perusahaan swasta kehutanan dan masyarakat dalam mengelola kawasan secara bersama-sama. Kasus yang terjadi di Kalimantan Tengah dan Barat ini bermula dari pemberian izin konsesi hutan yang diberikan oleh pemerintah pusat, dalam hal ini Kementerian Kehutanan, kepada perusahaan Sari Bumi Kusuma. Ternyata, di 
dalam kawasan konsesi terdapat sembilan desa yang masuk wilayah konsesi. Masyarakat sudah hidup secara turun-temurun di desa-desa tersebut. Kesembilan desa ini masuk di pedalaman dan sulit djangkau karena akses jalan yang belum tersedia. Jalur transportasi tradisional adalah dengan menggunakan jalur sungai. Butuh waktu berharihari dengan medan sungai yang berarus deras untuk bisa sampai ke desa yang terdekat. Masyarakat yang tinggal di daerah 'pedalaman' seringkali digambarkan sebagai masyarakat yang tersingkir karena adanya proses 'pembangunan' atau juga eksploitasi sumber daya alam yang ada di sekitar kehidupannya dan negara berperan besar membantu perusahaan untuk 'menyingkirkan' masyarakat (Li, 2002).

Masyarakat dan perusahaan adalah dua pihak yang 'terikat' dengan keputusan negara mengenai izin pengelolaan kawasan hutan. Dalam keputusan tersebut, penentuan hutan konsesi yang dikelola oleh PT. Sari Bumi Kusumabukan berdasarkan kondisi di lapangan, melainkan pemetaan yang ada di Jakarta. Seiring dengan beroperasinya perusahaan, terjadi interaksi antara masyarakat dan perusahaan. Interaksi tersebut mengalami pasang surut, adakalanya terjadi konflik dan ada kalanya juga terjadi kolaborasi. Untuk mengatasi kondisi tersebut, perusahaan dan negara melakukan upaya-upaya melibatkan masyarakat dalam pembangunan dan pengembangan wilayah melalui sinergi program. Pertimbangan perusahaan terlibat dalam program pemberdayaan adalah menghindari pontensi ancaman berupa gangguan dari masyarakat dan sebagai bentuk tanggung jawab sosial yang dimiliki,maka swasta membantu negara dalam menjalankan peran-perannya berupaya pelayanan publik. Peran dan kehadiran perusahaan dalam konteks ini perting untuk dilihat sebab terdapat dualisme. Di satu sisi, sebagai warga negara, masyarakat di desa-desa tersebut menjadi tanggung jawab pemerintah dalam memberikan pelayanan dan pemenuhan hak-hak sipil.Namun, di sisi lain wilayah desa-desa tersebut berada di dalam konsesi yang dikelola oleh swasta.

Alasan lain dari pilihan pemberdayaan dan pemberian hak-hak masyarakat yang dilakukan oleh perusahaan adalah supaya swasta dapat terus berproduksi menghasilkan kayu-kayu dan masyarakat dapat berdaya dengan menggali potensi yang terdapat di dalam desanya. Untuk itu, kajian ini menyoroti peran aktif swasta dalam memberdayakan masyarakat di kawasan konsesi. Peran tersebut dilakukan selain sebagai bagian dari tanggung jawab sosial juga sebagai upaya pembangunan kehutanan sosial. Usaha-usaha mengatasi permasalahan kehutanan dengan melibatkan masyarakat di beberapa tempat dianggap berhasil, seperti di Selandia Baru (Tipa \& Welch, 2006). Dalam konteks artikel ini, keterlibatan swasta dalam memberdayakan masyarakat juga terkait dengan 'ketidak-hadiran' negara atau pemerintah dalam memenuhi kebutuhan masyarakat.

Masyarakat yang tinggal di dalam hutan konsesi dapat dikategorikan sebagai masyarakat yang marjinal, yakni masyarakat yang terbatas aksesnya pada sumber daya (Ribot dan Peluso, 2003), lahan,modal, pengetahuan dan teknologi, sertaterhadap market (Marin-Burgos, 2014). Akibatnya, masyarakat tidak dapat secara cekatan merspon perubahan yang ada di luar. Dampak lain adalah masyarakat kurang mendapatkan beberapa hak yang seharusnya mereka dapatkan dari negara, seperti pelayanan kesehatan, pendidikan, infrastuktur, dan lain sebagainya.

Kajian ini penting dilakukan karena selama ini, ketika berbicara tentang relasi dengan melibatkan negara, maka definisi orang akan merujuk pada pengertian negara dilihat sebagai sistem politik yang memiliki kekuasaan melalui aktor-aktor yang terdapat di dalamnya. Negara dimaknai sebagai sistem politik dan pemerintahan yang memberikan kontrol terhadap masyarakat, baik dalam pembentukan formasi negara maupun dalam operasionalnya (Corrigan, 1994; Eilenberg, 2012; Hansen \& Stepputat, 2001; Migdal, 2001; Eilenberg, 2012). Dengan cara pandang seperti itu, maka yang selalu terlihat adalah adanya konflik antara masyarakat dan negara, walaupun tidak dipungkiri bahwa konflik memang terjadi (Contreas-Hermosila dan Fay 2005, Barr 2002, Peluso 1993, 1998). Idealnya, melihat konflik antara masyarakat dan negara atau dengan pihak lainnya adalah sebagai rangkaian proses yang belum tuntas.Selalu ada pasang surut. Adakalanya terjadi konflik dan tidak jarang terjadi kesepakatan.

Dalam pengelolaan secara bersama ini, swasta diantaranya memberikan pelayanan dan mengadvokasi masyarakat untuk secara optimal mengelola potensi daerahnya. Peran-peran perusahaan sebagai bentuk tanggung jawab sosial terhadap masyarakat mengikuti proses-proses yang disyaratkan oleh negara. Swasta melakukan pengawasan, pemetaan kondisi geografis dan konflik secara partisipatif, pendataan jumlah penduduk, memberikan 
pelayanan kesehatan dan pendidikan, serta membangun infrastruktur. Dalam perspektif yang lain, tindakan-tindakan yang dilakukan oleh swasta adalah proses bagaimana kekuasaan itu dapat dicapai (Corrigan, 1985), yakni kekuasaan terhadap sumber daya. Untuk itu, artikel ini menjelaskan relasi-relasi yang terjadi antara masyarakat dan perusahaan. Ada dinamika atau pasang surut dalam relasi keduanya. Hal ini bukan hanya persoalan perebutan sumber daya tetapi juga ada faktor-faktor lainnya yang turut mempengaruhi.

\section{Kehidupan Masyarakat di Lahan Konsesi}

Memang tidak ada kesibukan, paling ketika ada yang mengurus kartu penduduk atau ada bantuan beras bagi rakyat miskin, itu pun tidak lama. Jika tidak ada, kami hanya duduk-duduk seperti ini, di kantor maupun di rumah sama saja. Sesekali saya bergabung dengan masyarakat, jika ada keperluan. Mengenai program lainnya kami tidak punya, silahkan tanya ke SBK(staf kecamatan).

Berdasarkan data yang diperoleh, terdapat setidaknya tujuh desa yang ada di Kalimantan Barat dan sembilan desa di Kalimantan Tengah yang masuk dalam wilayah konsesi Sari Bumi Kusuma.Kesembilan desa tersebut adalah Desa Tanjung Paku, Riam Batang, dan Tumbang Teberau (Kecamatan Seruyan Hulu, Kabupaten Seruyan); Desa Tumbang Kaburai, Tanjung Batik, Tumbang Karuei, dan Tumbang Kajamei (Kecamatan Bukit Raya, Kabupaten Katingan); serta Desa Kiham Batang dan Rangan Kawit (Kecamatan Katingan Hulu, Kabupaten Katingan). Kesembilan desa ini dalam kesehariannya hidup seolah-olah 'tanpa negara'. Berbagai keperluan dan pelayanan diberikan oleh perusahaan SBK (Sari Bumi Kusuma).

Berdasarkan sejarah perusahaan, izin pengelolaan hutan PT. Sari Bumi Kusuma sejak dikeluarkannya Forestry Agreement (FA) No. FA/N/016/III/1978 pada tanggal 29 Maret 1978 dan SK Menteri Pertanian No. 599/Kpts/Um/11/ 1978 pada tanggal 18 November 1978 tentang Pemberian Hak Pengusahaan Hutan menyatakan bahwa luas hutan yang dikelola adalah 84.000 ha (kelompok hutan Sungai Delang). Berdasarkan Add. FA/N-AD/045/VII/1979 yang dikeluarkan pada tanggal 14 Juli 1979, luas areal konsesi bertambah menjadi 270.000 ha (penambahan luas 186.000 ha berada di kelompok hutan Sungai Seruyan).
Setelah masa pengusahaan hutan jangka waktu pertama (20 tahun) berakhir, IUPHHKHA PT. Sari Bumi Kusuma memperoleh perpanjangan konsesi berdasarkan SK. Menhut No. 201/Kpts-II/1998 yang dikeluarkan pada tanggal 27 Februari 1998 dengan pengelolaan Hutan Tanaman Industri dengan sistem Tebang Pilih dan Tanam Jalur (HPHTI-TPTJ). Luas areal kerja seluruhnya $208.300 \mathrm{Ha}$ yang terbagi dalam kelompok hutan Sungai Seruyan seluas 147.600 Ha dan kelompok Hutan Sungai JelaiSungai Delang seluas 60.700 ha. Berkurangnya luas areal tersebut karena telah dikeluarkannya areal hutan yang berfungsi sebagai hutan lindung dan peruntukkan lain dari areal pengelolaan (Sari Bumi Kusuma, 2017).

Ketika perusahaan ini mulai beroperasi, ternyata banyak desa atau pemukiman masyarakat yang masuk dalam kawasan konsesi. Pada awal mula beroperasinya perusahaan, sering terjadi konflik antara perusahaan dan masyarakat, terutama pada persoalan batas wilayah, antara wilayah masyarakat, wilayah adat, dan wilayah perusahaan. Dalam praktik pemanenan hasil hutan, seringkali perusahaan dituduh mengambil kayu dari wilayah adat atau wilayah hutan yang dikelola dan peruntukannya sebagai persediaan berbagai macam kebutuhan masyarakat.

Konflik dengan masyarakat mengganggu produktivitas perusahaan dalam memperoleh keuntungan. Ketika konflik terjadi, karyawan yang bertugas menebang pohon dan mengangkut kayu hasil tebangan tidak berani bekerja karena mereka dihadang oleh masyarakat yang protes. Jika kondisi demikian terus dibiarkan akan berdampak kurang baik bagi operasional perusahaan. Oleh karena itu, kemudian perusahaan pun membentuk satu divisi tersendiri yang bertugas 'menangani' masyarakat lokal, yaitu PMDH (Pembinaan Masyarakat Desa Hutan) yang bertugas memberdayakan masyarakat. Dalam menjalankan programnya, PMDH melakukan pendekatan pada masyarakat dan berinteraksi secara langsung dengan masyarakat.

Bila merunut sejarah, kehadiran perusahaan di pedalaman dan di batas-batas negara bukanlah sesuatu yang baru. Perusahaan swasta yang terdapat di wilayah perbatasan Indonesia-Malaysia memang sengaja dimasukkan oleh 'negara' sebagai klaim atas wilayah dan representasi dari kehadiran negara, melalui izin yang dikeluarkan (Ishikawa, 2012). Sementara itu, dari sisi perusahaan, penggarapan daerah tersebut berdasarkan alasan 
ekonomi, yakni menguntungkan secara finansial, karena masih banyak potensi alam yang bisa dieksplorasi dari kawasan yang diberikan izin.

Mendatangi desa-desa yang masuk area konsesi perusahaan Sari Bumi Kusuma, akan terlihat secara umum kondisi desa hampir seragam,yaitu adanya akses jalan darat yang menggunakan jalan perusahaan serta fasilitas kendaraan sebagai alat transportasi mereka. Sementara itu, bila melalui jalur sungai, belum ada transportasi publik. Hanya ada perahu milik perorangan yang bisa kita gunakan untuk disewa. Bangunan kantor kepala desa pun tidak ada. Hanya ada bangunan kantor kecamatan di desa Tumbang Kajame sebagai pusat kota kecamatan.

Beberapa ruas jalan yang terdapat di desa tampak terlihat rusak parah, hanya beberapa ruas jalan yang masih bagus, itu pun menggunakan beton, dan menurut penuturan warga, perbaikan jalan ini merupakan bantuan dari perusahaan. Pihak perusahaan memang memberikan bantuan sarana dan prasarana untuk warga desa, dari perbaikan jalan, bantuan air bersih, sampai pada kepentingan pribadi dalam memasarkan hasil ladang atau ternak.Negara baru terlihat hadir, melalui aktor-aktornya, menurut Kepala Desa yang saya jumpai ketika ada proses pengurusan administrasi seperti Kartu tanda Penduduk, Kartu Keluarga, Akte Kelahiran, saksi jual beli ladang, dan penyaluran bantuan raskin (beras rakyat miskin).

Masyarakat tersebut masuk dalam etnis Dayak. Ada ragam sub-etnis Dayak yang menetap di lokasi ini. Mata pencaharian utama mereka adalah bertani ladang berpindah untuk memenuhi kebutuhan hidupnya, selain berburu hasil hutan, baik binatang maupun hasil hutan bukan kayu lainnya. Namun, perkembangan terakhir menunjukkan bahwa banyak area yang pada mulanya ladang kini menjadi lokasi tambang emas yang dikelola secara sederhana. Banyaknya peralihan area hutan menjadi ladang emas menunjukkan bahwa aktivitas ini menggiurkan masyarakat. Banyak warga yang beralih profesi dari peladang menjadi petambang.

Fasilitas umum maupun pendidikan yang terdapat di setiap desa, seperti satu unit sekolah maupun balai adat, adalah bantuan dari perusahaan. Dari tiga orang guru yang mengajar di sekolah, dua tenaga pendidiknya berasal dari perusahaan. Tiap sekolah terdapat dua tenaga pendidik yang berasal dari karyawan perusahaan.
Jalan dan berbagai fasilitas sosial yang terdapat di desa umumnya diperoleh dari bantuan perusahaan. Ada memang proyek dari negara, melalui PNPM Mandiri, tetapi jumlahnya sangat terbatas dan 'tidak membekas' secara kuat dalam ingatan masyarakat.

Bagi sebagian kalangan mungkin mengira bahwa masyarakat ini terisolasi sejak lama dan tidak melakukan interaksi dengan masyarakat di luar. Namun, jika ditelusi lebih jauh,secara tersirat terlihat adanya jejak-jejak tradisi yang menunjukkan bahwa mereka telah lama berinteraksi dengan kelompok etnis lain. Ini misalnya terlihat dalam penggunaan mantra-mantra, baik untuk tujuan penyembuhan maupun perlindungan lahan dari serangan hama dan hasil yang kurang maksimal. Dari data yang diperoleh, mereka melafalkan mantra-mantra yang diawali dengan bismillah dan diakhiri dengan Muhammadurrosulillah. Sementara itu, di pertengahan mantra menggunakan bahasa daerah yang sebagain anak-anak muda sudah tidak memahami lagi artinya. Bismillah dan muhammadrosulilah adalah kalimantkalimat yang identik dengan ajaran Islam.

Penelusuran lebih lanjut menunjukkan bahwa mereka membaca mantra ini berdasarkan pengetahuan yang turun-temurun, tanpa ada penambahan dalam kalimat mantra. Bahkan, menurut beberapa informan yang dijumpai, ayah dari kakeknya sudah menggunakan kalimat ini ketika membaca mantra untuk tujuan pengobatan maupun membuka ladang baru. Jejaklainnya yang merujuk pada adanya interaksi dengan Islam adalah penggunakan kata sahabat untuk menyebut kekuatan gaib. Bila ditelusuri, kata sahabat berakar dari bahasa Arab, shohabat yang berarti teman atau juga temannya Nabi, yaitu orang-orang yang percaya dan beriman pada Nabi Muhammad. Sahabat pun memiliki peran tersendiri dalam sejarah Islam.

Penggunaan mantra yang mengandung kata dalam Bahasa Arab dilakukan oleh Pak timbas (68 tahun) dan yang lainnya, sebagai salah satu cara tradisional dalam mengusir hama di ladang. Ketika melafalkan mantra untuk melindungi ladangnya Pak Timbas menggunakan kata-kata bahasa Arab (bismillah) dan menyebut nama Nabi Muhammad. Menurutnya ini diperoleh secara turun temurun dari beberapa generasi sebelumnya. Dia sendiri tidak mengetahui sejak kapan mantra tersebut ada di masyarakat. Dia hanya mendapatkan mantra tersebut dari bapaknya. 
Selain mantra yang menggunakan kata Arab dan kata Sahabat yang menunjukkan 'kekuatan besar', masyarakat Dayak di konsesi SBK juga memiliki persepsi sendiri tentang Nabi Muhammad. Dalam pandangan mereka, Nabi Muhammad bukan hanya Nabinya orang Islam, melainkan Nabi untuk semua manusia (Nabi universal) yang tidak pilih kasih.Siapa saja yang menyebut dan memanggil namanya akan dibantu. Nabi ini sangat baik. Nabi Muhammad adalah 'penguasa tertinggi' alam dan berbagai pujian terhadap Nabi Muhammad.

Kajian dari Wolf (1982) tentang masyarakat pedalaman di hutan Amazon menunjukkan bahwa masyarakat pedalaman yang sering disebut 'primitif' serta seolah terisolasi dan tidak pernah berinteraksi dengan kelompok masyarakat lainnya justru menunjukkan bahwa mereka memiliki interaksi dengan kelompok di luar dirinya dalam rentang waktu yang cukup lama. Interaksi ini terus diceritakan dan menjadi sejarah mereka.Justru yang tidak memiliki sejarah adalah masyarakat yang mengklaim dirinya modern dan maju, atau masyarakat Eropa (Wolf, 1982).

\section{Pembinaan Masyarakat Desa Hutan (PMDH) dan Representasi Swasta}

Pernah kami tawarkan ke masyarakat bahwa dana yang biasa kami sediakan untuk membantu masyarakat (penyediaan transportasi, bantuan bibit, pupuk, dan lain sebagainya) dikelola oleh kecamatan. Jadi nantinya tidak ada hubungan antara masyarakat dan perusahaan. Semuanya diatur oleh kecamatan, tetapi masyarakat menolaknya (Staf PMDH).

Dalam memberikan tanggung jawab sosial yang dimandatkan oleh negara, perusahaan Sari Bumi Kusuma membentuk satu divisi yang bernama PMDH (Pembinaan Masyarakat Desa Hutan). Tujuannya adalah untuk membantu meningkatkan kesejahteraan dan taraf hidup masyarakat yang ada di lahan konsesi dengan beberapa program, seperti pembinaan pertanian menetap, peningkatan ekonomi masyarakat, pengembangan sarana dan prasarana umum, pengembangan sosial budaya, dan konservasi sumber daya hutan dan lingkungan (www.sari bumikusuma.com).

Setiap tahun, perusahaan mengeluarkan dana yang cukup besar yang dikelola oleh PMDH. Informan kami yang merupakan staf PMDH tidak menyebut jumlah yang pasti, tetapi dana yang dikeluarkan kira-kira 6,5 milyar per tahun, termasuk di dalamnya adalah gaji karyawan. Dana tersebut dikeluarkan untuk berbagai bantuan pupuk, bibit, transportasi, dan menjalankan program-program perusahaan (PMDH). Angka tersebut cukup besar untuk mengurusi kebutuhan dan memberikan pelayanan sembilan desa yang masuk dalam area konsesi perusahaan.

Pilihan program-program yang dilakukan oleh PMDH terkait dengan pemberdayaan masyarakat membantu tugas-tugas negara yang belum maksimal dalam melayani warganya. Bahkan, program yang digulirkan oleh PMDH terkait dengan pemberdayaan masyarakat dilakukan sudah lama, yakni sejak tahun 1980an. Programprogram awal yang disusun oleh PMDH masih bermasalah karena melihat masyarakat sebagai objek dan tanpa adab atau 'primitif'. Seiring dengan berjalannya waktu dan interaksi yang intensif diketahui bahwa masyarakat juga memiliki kecerdasan tersendiri. Bahkan beberapa anakanak yang dari desa sudah ada yang telah sarjana. Akan tetapi, perubahan cara pandang perusahaan terhadap masyarakat lokal pun tidak sampai mengubah kata 'pembinaan' dan program yang telah ditetapkan, melainkan sebatas pada cara bagaimana mereka berinteraksi dengan masyarakat. Artinya, pemahaman yang dimiliki oleh staf baru perusahaan hanya berganti baju, tetapi inti atau perlakukan perusahaan terhadap masyarakat masih tetap sama.

Dalam menjalankan misi perusahaan, PMDH memfasilitasi kepentingan dan kebutuhan masyarakat terhadap perusahaan. Dari penyediaan bibit, pupuk, sampai pada pembangunan infrastruktur melalui berbagai program yang digulirkan. Namun, program ini berdampak kurang baik, yakni menciptakan ketergantungan. Masyarakat justru menjadi "manja"dan kurang optimal dalam mengembangkan potensi diri dan sumber daya yang dimiliki. Namun, dengan adanya perubahan dan perkembangan masyarakat, juga masuknya staf baru di PMDH, sedikit banyak mempengaruhi 'budaya organisasi' yang ada. Bila dulu perusahaan memandang masyarakat lokal sebagai 'objek' dari pemberdayaan, sekarang paradigma tersebut telah bergeser menjadi masyarakat adalah 'subjek' dari pembinaan itu sendiri. Namun, staff barupun harus merujuk pada lima program yang di atas, hanya saja 'pendekatan yang beda'. 
Berdasarkan data lapangan, diketahui bahwa pertanian menetap sudah sangat lama diprogramkan, demplot pun sudah lama dibikin. Namun, hal ini tidak juga kunjung mengubah masyarakat dalam hal berladang. Menurut PMDH, program ini disusun untuk mengubah masyarakat dari perladangan berpindah menjadi perladangan menetap. Program-program tersebut disusun untuk mengalihkan perhatian warga dari aktivitas yang dilakukan oleh SBK. Namun, dalam pelaksanaannya, masyarakat tidak juga mengubah praktik perladangan mereka.

Dari satu kacamata, program-program yang dilakukan oleh PMDH tampak tidak berhasil dan seolah hanya sedang menutupi prilaku lainnya, berupa 'perampasan' hak-hak warga terhadap tanah dan hak-hak lainnya yang bisa diperoleh.Namun, dari perspektif lain, program-program PMDH adalah media interaksi antara masyarakat dengan orang luar, dan dari interkasi tersebut, perubahan di masyarakat terlihat lebih nyata.

Dalam melihat ketidak berhasilan programprogram PMDH, pemikiran Scott (1998) sangat relevan, terutama mengenai masyarakat yang direkayasa oleh skema-skema pembangunan hanya akan menghasilkan manusia-manusia pasif yang tak sejalan dengan tujuan pembangunan itu sendiri. Masyarakat yang berhasil adalah masyarakat yang bebas untuk menentukan cara meraih keberhasilannya sendiri, bukan yang direkayasa dari atas. Pembangunan itu seharusnya, bagaimana membuat masyarakat yang tak berdaya menjadi berdaya. Hal ini terlihat dari 'ketidak berhasilan' program pertanian menetap yang dilakukan oleh PMDH terhadap masyarakat lokal. Kebijakan tersebut tidak mengubah prilaku masyarakat dalam bertani, padahal program tersebut sudah berjalan lebih dari tiga puluh tahun.Selain itu, program bantuan dari PMDH juga membuat masyarakat menjadi pasif. Masyarakat lokal tidak memiliki inisiatif dalam melakukan perubahan. Mereka selalu menunggu dan bergantung terhadap bantuan dari perusahaan, jika tidak ada bantuan yang datang maka mereka tidak melakukan apapun. Hal ini pun disadari oleh staff perusahaan yang berwenang dalam 'membina' masyarakat.

Ketidak-berhasilan program PMDH dan ketergantungan masyarakat lokal itu selain disebabkan program yang dijalankan tidak tepat dengan 'budaya' mereka, juga bisa dilihat sebagai salah satu bentuk 'pembangkangan' yang dilakukan oleh petani. Etika subsistensi, yakni etika untuk bertahan hidup dalam kondisi minimal melandasi segala perilaku kaum tani dalam hubungan sosial mereka di pedesaan, termasuk pembangkangan mereka terhadap inovasi yang datang dari penguasa mereka (Scoot 1998). Penguasa dalam konteks ini bukan negara, melainkan perusahaan yang berperilaku layaknya negara.

Walaupun demikian, kehadiran perusahaan dengan berbagai programnya, yang memungkinkan adanya interkasi masyarakat dengan orang luar yang dianggap terdidik dan maju oleh masyarakat, telah mengubah kondisi sosial-budaya masyarakat. Dalam hal pendidikan misalnya. Kehadiran pendidikan telah mengubah orientasi kehidupan masyarakat yang sebelumnya berorientasi ke masa lalu menjadi berorientasi ke masa depan. Sebelum masyarakat mengenal sistem pembelajaran melalui sekolah, orientasi masyarakat dalam melakukan aktivitasnya terutama berkaitan dengan ekonomi dan keuntungan materi supaya bisa melaksanakan upacara Tiwah, yakni upacara penyempurnaan kematian seseorang. Pelaksanaan upacara ini menghabiskan dana yang tidak sedikit, tidak jarang orang menjual ladang dan menghabiskan tabungan hanya mengejar gengsi telah melaksanakan upacara Tiwah untuk leluhurnya. Setelah kehadiran sekolah dan interaksi yang terus menerus antara staf PMDH dan masyarakat, maka lambat laun orientasi masyarakat berubah. Sebagian besar masyarakat kini lebih melihat pendidikan dan sekolah sebagai prospek untuk memberikan kesejahteraan bagi anak-anaknya.

Perubahan tersebut berdampak pada aktivitas yang berkaitan dengan pengelolaan sumber daya. Bila dulu aktivitas berladang maupun pengumpulan sumber daya lainnya (seperti ternak babi, sapi, dan ayam) tidak saja bertujuan untuk memperkaya diri melainkan juga menyimpan sebagian kekayaannya untuk melakukan upacara Tiwah, maka kini simpanan kekayaan supaya bisa membiayai anak-anak untuk sekolah, bahkan berusaha sampai jenjang tertinggi. Hal ini menunjukkan bahwa interaksi sosial tidak selalu dibaca sebagai relasi kuasa tetapi proses-proses keseharian yang silang sengkarut dan di luar dari garis kebijakan. Kasus ini serupa dengan yang terjadi di perbatasan ketika negara hadir justru bukan berupa kekuasaan melainkan melalui interaksi dalam keseharian (Eilenberg, 2012). Dalam konteks ini, dalam interaksi antara swasta melalui mandor dan masyarakat terjadi proses saling 
serap dan hubungan-hubungan yang tidak lagi berorientasi kekuasaan. Di dalamnya ada dinamika tersendiri sehingga memungkinkan adanya perubahan perspektif dan orientasi masyarakat terhadap suatu praktik budaya yang sudah lama dilakukan.

Perubahan oreintasi juga terjadi dalam praktik berladang, secara umum masyarakat Dayak yang tinggal di hutan konsesi SBKmasih melakukan praktik perladangan sebagai bagian dari kehidupannya. Praktik perladangan pun masih menggunakan cara-cara tradisional, baik dari persiapan sampai panen. Praktik ini walaupun terbukti mampu menjaga keanekaragaman biota dan sesuai dengan kaidah-kaidah ilmu pengetahuan (Dove, 1988; Soedjito, 1995), tetapi seiring dengan populasi orang yang kian meningkat dan sempitnya lahan membuat orang mulai berpikir ulang tentang praktik berladang secara tradisional. Persoalan lain dari ladang berpindah adalah kebutuhan lahan. Ini berarti ancaman bagi perusahaan yang kemungkinan lahannya akan digunakan untuk ladang.

Kondisi ini disadari oleh perusahaan. Oleh karena itu, perusahaan berinisiatif membuat demplot pertanian menetap dengan memberdayakan masyarakat setempat untuk membuatnya. Bahkan, beberapa orang berinisiatif sendiriuntuk mencoba mempraktikkan sistem perladangan menetap. Namun, program ini belum dapat dikatakan berhasil. Selain karena kondisi tanah yang tidak mendukung, daerah persawahan memerlukan perawatan yang intensif dan telaten, tidak seperti ladang. Beraktivitas rutin pada satu tempat serta belum berhasilnya usaha persawahan membuat orangorang meninggalkan aktivitas ini dan kembali membuat ladang.

Teknik penanaman padi melalui persawahan tidak sesuai dengan karakter masyarakat setempat. Alasan kegagalan diantaranya karena perlakuan terhadap sawah sama dengan perlakuam terhadap ladang. Dari menanam sampai memanen. Ketika menanam, alat yang digunakan pun masih sederhana, sama dengan alat yang digunakan untuk ladang. Setelah ditanam, sawahpun ditinggalkan dan tidak diurus seperti halnya ladang. Akibatnya, padi tidak tumbuh dengan baik dan lebih rentan terserang hama.

Para pelaku persawahan umumnya orang-orang yang sudah dianggap tua. Alasan dipilihnya kegiatan bersawah adalah hasil lebih pasti dan bisa diduga, walaupun dalam beberapa kali panen tidak sesuai dengan harapan. Alasan lainnya adalah tidak terlalu banyak hama yang berupa serangan binatang (babi, monyet, atau burung).Lebih lanjut, dalam bersawah, tidak terlalu banyak tenaga yang dikeluarkan sehingga lebih efektif. Ketika mulai menanam di sawah, maka ladang-ladang dan kebun yang dimiliki tidak lagi dianggap sebagai sumber ekonomi yang dapat memenuhi kebutuhan harian, tetapi dianggap sebagai investasi masa depan, terutama untuk menyiapkan biaya kebutuhan anak untuk sekolah. Ladang dan kebun akan dijual ketika anak hendak masuk perguruan tinggi yang membutuhkan banyak biaya.

Dalam menjalankan program-program pemberdayaan, pihak perusahaan juga harus berhadapan dengan negara. Sebagian dari staff SBK dalam melihat negara atau representasinya melalui aktor-aktor di pemerintahan daerah sebagai wujud ancaman yang perlu diwaspadai. Ancaman disini lebih pada klaim-klaim terhadap usaha dan kerja SBK. Pandangan demikian didasarkan pada interaksi sebelumnya yang seringkali usaha-usaha pemberdayaan maupun program lainnya yang dilakukan oleh SBK diklaim sebagai usaha atau program yang telah dilaksanakan oleh negara. Seperti yang terjadi pada tahun 2008, pemerintah setempat memiliki dana 98 Milyar untuk rehabilitasi hutan. Pihak SBK mengetahui itu karena sering diajak berkerja sama dalam suatu rapat. Sebelum kesepakatan kerjasama ditandatangani, negara "menghilang" dan lalu diketahui bahwa pohon meranti dan karet yang ditanam oleh SBK diklaim sebagai program yang dijalankan oleh pemerintah.

Kasus-kasus seperti ini membuat perusahaan lebih berhati-hati ketika menjalankan program pemberdayaan masyarakat. Untuk mengantisipasinya, program yang dilaksanakan diberikan penanda yang menunjukkan bahwa kegiatan tersebut dijalankan oleh perusahaan. Masyarakat sendiri tidak mengetahui konflik kepentingan yang terjadi antara perusahaan dan negara.

\section{Membangun Bersama: Dinamika Interaksi antara Perusahaan dan Masyarakat}

Pada awal-awal beroperasi, ketika pendekatannya adalah legal-formal semata, sering terjadi konflik antara perusahaan dan masyarakat. Konflik bermula dari adanya penolakan penebangan hutan adat dan hutan yang penting bagi masyarakat oleh perusahaan. Seiring dengan interkasi yang terus terjadi, pihak perusahaan mulai menyadari bahwa di dalam kawasannya terdapat masyarakat 
yang memiliki tradisi dan kaitan dengan hutan. Walaupun secara legal-formal masuk dalam konsesi, tetapi perusahaan tetap menghormati hak-hak adat masyarakat. Beberapa kawasan hutan adat tidak ditebang oleh perusahaan. Demikian juga hutan keramat dan bekas ladang masyarakat. Keputusan ini, selain dasarnya adalah kesadaran dari pihak perusahaan, juga sebagai bagian dari kesepakatan pengelolaan hutan secara berkeanjutan.

Selain kesepakatan tentang tidak menebang hutan adat dan keramat, terdapat juga kesepakatan mengenai pemberdayaan dan bantuan masyarakat. Kesepakatan-kesepakatan ini menjadi ruang baru bagi perusahaan dalam interaksinya dengan masyarakat. Program-program pemberdayaan dan pembangunan disusun untuk memenuhi kebutuhan masyarakat, walaupun tidak semua tuntutan masyarakat dapat dipenuhi oleh perusahaan. Adanya ruang baru memungkinkan bagi perusahaan untuk lebih intensif dalam berinteraksi dengan masyarakat. Meskipun demikian, sebetulnya sebelum adanya peraturan mengenai tanggung jawab sosial perusahaan, SBK sudah melakukan kegiatan-kegiatan yang disebut oleh mereka sebagai pemberdayaan masyarakat dan supaya masyarakat terlibat aktif dalam pembangunan.

Pada dasarnya pembangunan adalah wacana yang dalam praktiknya menggunakan beberapa cara supaya masyarakat dapat diarahkan atau didisiplinkan sesuai dengan kehendak produser wacana (Foucault, 1995). Hal ini dilakukan supaya 'kekuasaan' yang ada pada perusahaan dapat terus dijalankan. Oleh karena itu, seluruh aktivitas masyarakat harus diketahui oleh perusahaan. Pengawasan yang menyeluruh tersebut biasa disebut dengan panopticon (Foucault, 1995) yang melahirkan praktik-praktik tertentu supaya masyarakat dapat disiplinkan, seperti dalam kasus di Sulawesi (Li, 2012).

Dalam konteks penelitian ini, cara yang digunakan untuk berinteraksi dengan masyarakat adalah penempatan mandor dan membuat kantor perwakilan di setiap desa yang masuk dalam konsesi. Kantor ini diisi oleh seorang mandor (staf perusahaan) dan dua karyawan yang diambil dari warga setempat. Rutinitas keseharian mereka adalah memastikan program yang telah ditetapkan oleh PMDH dilakukan. Misalnya mengurus demplot, membantu warga, mengatur jadwal keperluan warga terhadap perusahaan, dan lain sebagainya yang berkaitan dengan hubungan masyarakat dan perusahaan. Di setiap kecamatan atau wilayah-tergantung letak geografis - terdapat seorang kordinator lapangan (seperti camat) yang bertugas mengkordinasi para mandor, guru bantu, dan bantuan perusahaan lain untuk masyarakat. Kordinator ini juga terkadang bertugas menfasilitasi mandor dan perusahaan.

Dalam usaha pemberdayaan dan berelasi dengan masyarakat, selain memberikan bantuan dan fasilitas untuk masyarakat, perusahaan juga menempatkan guru bantu yang bertugas mengajar di sekolah-sekolah yang gedungnya dibangun oleh perusahaan serta menempatkan mandor di tiap-tiap desa. Mandor ini bertugas menadampingi masyarakat dalam menjalankan program-program yang telah ditetapkan oleh perusahaan, walaupun secara substansial program tersebut tidak begitu efektif dalam mengubah perilaku masyarakat.

Sebagai representasi perusahaan, dalam keseharian, tugas mandoradalah melaporkan aktivitas harian masyarakat, mencatat jumlah penduduk, melakukanpenyuluhan, dan berbagai aktivitas lainnya dalam "membantu" masyarakat. Terkadang, mandor juga menjadi fasilitator dalam konflik. Setiap gerakan masyarakat tidak luput dari pengawasan mandor. Pada pagi hari, mandor sudah harus bangun dari pos (rumah warga yang disewa) untuk kemudian "absensi kehadiran" melalui radio pada kantor PMDH sambil melaporkan situasi yang terjadi pada rentang waktu malam sebelumnyahingga pagi tadi. Tugas melaporkan biasanya dilakukan oleh salah satu karyawan yang berasal dari desa. Melalui sistem pelaporan tersebut, perusahaan dapat mengetahui siapa sedang butuh apa, siapa pergi kemana, siapa sedang melakukan apa, dan lain sebagainya mengenai gerak-gerik masyarakat. Tim penulis pun pernah mengalami, berdasarkan jadwal yang telah kami susun, di hari tertentu kami harus mengunjungi desa A.Namun, berdasarkan informasi dari karyawan perusahaan, lebih baik jadwal dirubah, karena di desa B sedang ada aktivitas masyarakat yang bagus untuk dilihat. Karyawan tersebut mendapatkan informasi tersebut dari mandor. Maka Tim pun mengubah jadwal.

Mandor adalah "garda depan" perusahaan dalam berhadapan dengan masyarakat. Jika ada tuntutan atau apapun terkait dengan kepentingan masyarakat terhadap perusahaan, mandor akan berusaha semaksimal mungkin untuk menyelesaikannya di tingkat desa, supaya tidak menyebar ke desa lainnya dan juga tidak sampai ke kantor 
perusahaan. Selain mandor, perusahaan juga mengangkat tenaga harian untuk bekerja di perusahaan, terutama dalam membantu tugas mandor. Tenaga harian ini biasanya berasal dari masyarakat desa setempat.

Biasanya konflik yang terjadi antara perusahaan dan masyarakat tidak berkaitan dengan lahan, melainkan karena ada masyarakat yang merasa tidak mendapatkan bagian yang setara dengan lainnya dalam hal bibit karet, bibit sayuran, pupuk, atau kesempatan bekerja. Konflik pun terjadi karena permintaan transportasi masyarakat desa tidak segera dipenuhi oleh perusahaan. Konflik antara masyarakat dan perusahaan belum bersifat masif. Alasan tidak adanya konflik yang tidak meluas karena sebelum perusahaan ini beroperasi, telah dilakukan kesepakatan antara perusahaan dan masyarakat. Kesepakatan tersebut diantaranya berbunyi bahwa perusahaan tidak akan menebang pohon buahbuahan, kayu yang dibutuhkan oleh masyarakat, pohon damar, tempat-tempat penting, dan lainnya. Imbalannya, masyarakat tidak akan mengganggu operasional perusahaan. Tampaknya kesepakatan ini dihormati oleh kedua belah pihak.

Media atau ruang lain yang digunakan oleh perusahaan, melalui mandor, dalam berinteraksi dengan masyarakat adalah melalui program demplot pertanian menetap. Program pertanian memungkinkan mandor berinteraksi dengan masyarakat secara lebih luas. Tiap hari, mandor bertemu tidak saja dengan masyarakat yang membuat demplot tetapi juga masyarakat lainnya.

Dalam berinteraksi dengan masyarakat, mandor "mendapa" tempat tersendiri. Ia merupakan simbol dari perusahaan yang harus dihormati oleh masyarakat. Hal ini dapat terjadi karena sebagian besar masyarakat adalah karyawan harian lepas yang bekerja atas rekomendasi mandor. Dalam rapat-rapat warga, terutama terkait dengan sengketa-sengketa yang terjadi di masyarakat, suara mandor sangat diperhatikan. Bila berkaitan dengan relasi antara masyarakat dan perusahaan, pendapat mandor menjadi pertimbangan utama dalam pengambilan keputusan, seperti penentuan usulan jalan yang diperbaiki, penentuan warga yang berhak menerima bantuan, dan sebagainya.

\section{Membangun Imajinasi dan Kontrol: Demografi, Peta, dan Hak Tradisional}

Dari kecamatan atau kabupaten pun mengambil data dari kami untuk masalah penduduk, baik untuk keperluan raskin atau pemilihan (staf PMDH).

Dalam berinteraksi dengan masyarakat, swasta melalui program-program yang digulirkannya adalah suatu pondasi bangunan yang mencitrakan perusahaan. Dalam interaksi tersebut, swasta memberikan berbagai bantuan ke masyarakat, seperti pemberian sarana pertanian dan kebutuhan kolektif, transportasi masyarakat dari desa ke kota-yangdiberikan secara gratis melalui truk, pemberian berbagai bibit tanaman dan pupuk, dan lain sebagainya. Dari perspektif swasta, program bantuan tersebut adalah modal produksi yang harus kembali menguntungkan.

Untuk beberapa lama, terutama ketika PMDH dibentuk sampai dengan era reformasi, citra perusahaan adalah "Sinterklas" yang memberikan bantuan disaat masyarakat membutuhkan. Namun, seiring dengan dinamika yang ada di masyarakat dan perusahaan itu sendiri, pola relasi juga mengalami perubahan. Hadirnya aktoraktor baru di perusahaan mempengaruhi perspektif dan kebijakan perusahaan terhadap masyarakat. Bila dulu perusahaan menganggap masyarakat lokal sebagai objek dari pemberdayaan, kini paradigma tersebut telah bergeser menjadi masyarakat adalah subjek dari pembinaan itu sendiri. Dalam praktiknya, masyarakat diberikan stimulus supaya dapat mandiri dan melepas ketergantungan terhadap perusahaan. Akan tetapi, perspektif baru ini masih terjebak pada lima program yang di atas, hanya saja pendekatan yang dilakukan memang berbeda.

Dalam usaha mendukung citranya sebagai perusahaan yang baik terhadap masyarakat, maka perusahaan harus melakukan interaksi yang terus menerus dengan masyarakat. Penguasaan data kependudukan, kebutuhan masyarakat, dan hak masyarakat mutlak diperlukan. Dengan data ini, perusahaan bisa menentukan kapan suatu program digulirkan dan ke desa mana program itu akan tepat diberikan. Dari data yang ada, data kependudukan yang dimiliki oleh perusahaan sangat lengkap, bahkan lebih lengkap dari data penduduk yang biasa ditemukan di banyak desa di Indonesia. Data penduduk yang ada menyebutkan tidak hanya nama melainkan juga pekerjaan, suku, agama, pendidikan, dan lain sebagainya.

Data penduduk ini selalu diperbaharui setiap tiga bulan sekali. Setiap tiga bulan, perusahaan sudah mengetahui perkembangan masyarakat dan juga prediksi kebutuhan akan makanan dan sumber daya. Bertambahnya jumlah 
kelahiran berarti juga keperluan terhadap makanan akan meningkat dan berimplikasi pula pada prilaku orang yang memiliki tambahan anggota keluarga.Data kependudukan ini juga digunakan untuk memprediksi kebutuhan transportasi masyarakat yang masih menggunakan sarana perusahaan, jumlah bantuan yang diberikan, dan berbagai jenis pelayanan lainnya - termasuk juga persoalan penggunaan lahan untuk ladang. Tanpa adanya data yang jelas, perusahaan akan kesulitan menghadapi klaim yang dilakukan oleh masyarakat.

Cara lain yang digunakan selain melalui data demografi adalah pembuatan peta. Peta yang disusun oleh perusahaan, dengan melibatkan sebagian masyarakat, tidak saja tentang peta kewilayahan seperti batas desa, melainkan juga terkait dengan hak-hak adat masyarakat, seperti situs keramat, ladang, bekas ladang, serta bekas pemukiman. Peta yang dibuat juga memuat aktivitas-aktivitas masyarakat terkait dengan penggunaan lahan. Melalui peta ini, perusahaan sudah mengetahui bahwa suatu kawasan pada tahun ini digunakan sebagai ladang berpindah atau penggunaan lainnya yang dilakukan oleh masyarakat. Pembuatan peta seperti ini dapat digunakan oleh perusahaan sebagai modal relasi dengan masyarakat. Relasi ini seringkali dipahami sebagai alat kontrol terhadap populasi dan sumber daya yang ada dan efektif digunakan (Anderson, 1991).

Di dalam peta tersebut, tercantum batas wilayah dan aktivitas masyarakat terkait dengan kewilayahan, seperti apa yang boleh dan tidak boleh diambil, kapan suatu lahan dapat digunakan lagi sebagai ladang, dan pembangunan infrastruktur kebutuhan masyarakat. Dalam pelaksanaannya, perusahaan melibatkan berbagai lembaga yang dianggap dapat mewakili suara kepentingan masyarakat yang lebih luas. Pembuatan dan penyusunan peta hak-hak tradisional masyarakat terkait dengan sumber daya dilakukan oleh PMDH (Pembinaan Masyarakat Desa Hutan) dari perusahaan dengan dibantu oleh LSM (Lembaga Swadaya Masyarakat) yang aktif menyuarakan kepentingan lingkungan dan masyarakat yang tinggal di sekitar hutan, seperti TNC (The Nature Conservancy) dan FFI (Fauna dan Flora International). Peta yang dibuat mencakup sembilan desa yang terdapat di area konsesi perusahaan.

Pembuatan peta sebagai bahan relasi dan solusi dari persoalan yang dihadapi oleh masyarakat adalah bentuk simplifikasi persoalan dan cara penyelesaian yang terlalu teknis ( $\mathrm{Li}$, 2012). Persoalan-persoalan yang terdapat di masyarakat dianggap sederhana dan mudah diselesaikan. Padahalsejatinya permasalahan yang ada di masyarakat tidak hanya hak-hak tradisional melainkan juga hak-hak nontradisional. Pembuatan peta yang dilakukan dengan melibatkan banyak pihak di atas juga memasukkan kawasan tradisional atau hutan-hutan adat yang secara tradisi dikelola oleh masyarakat. Kawasan tersebut adalah kawasan yang tidak bisa ditebang oleh perusahaan. Selain kawasan tradisional adalah kawasan yang dapat dikelola oleh perusahaan.

Relasi antara masyarakat dan perusahaan dengan menggunakan peta sebagai panduannya dapat dipahami sebagai bentuk kontrolterhadap sumber dayadan aktivitas masyarakat. Bahkan, melalui pembuatan peta dan identifikasi hak-hak tradisional, perusahaan secara tidak langsung menunjukkan dominasinya terhadap masyarakat dalam relasi diantara keduanya (Roseberry, 1994). Walaupun pada saat yang bersamaan, masyarakat dapat melakukan penolakan dengan tidak mengakui peta yang disusun oleh perusahaan, tetapi di sini tidak terjadi seperti itu; masyarakat masih menerima penamaan, peta, dan identifikasi yang dilakukan oleh perusahaan.

Kerja-kerja perusahaan dalam pendataan masyarakat dan pembuatan peta sumber daya alam juga menunjukkan bahwa pengaturan atau kontrol terhadap sumber daya alam tidak menjadi monopoli negara, tetapi lembaga yang berperan sebagai negara juga melakukan hal tersebut (Trouillot, 2001). Dengan demikian, power atau kekuasaan melekat pada "negara". Pihak perusahaan melalui berbagai usaha penguasaannya melakukan berbagai pengaturan dan kontrol terhadap masyarakat. "Negara", dalam konteks ini adalah perusahaan swasta, seharusnya tidak lagi dipahami hanya sebagai sumber kekuasaan yang bisa memaksakan otoritasnya, akan tetapi perusahaan merupakan suatu cara yang digunakan untuk melakukan pengaturan oleh kelompok-kelompok yang lebih dominan (Hansen dan Stepputat, 2001).

Data demografi dan pembuatan peta kawasan juga membentuk identitas sendiri di masyarakat. Melalui data tersebut, masyarakat dicitrakan sebagai kelompok orang yang dalam kehidupannya dapat hidup dengan rukun bersama perusahaan karena adanya berbagai 
bantuan dan kemudahan yang diberikan perusahaan. Identitas kewarganegaraan yang dibentuk oleh perusahaan terhadap masyarakat desa yang dibentuk melalui kontrol dan lain sebagainya yang terjadi di Hulu Sungai Katingan ini agak mirip dengan yang terjadi di Desa Brassika, Klungkung, Bali (Parker, 2003). Masyarakat adalah "karyawan" tidak langsung dari perusahaan dan menjadi bagian dari perusahaan. Akibatnya, masyarakat pun lebih memilih terlibat dan berpartisipasi dengan program-program yang dibuat oleh perusahaan. Imaginasi dan ketergantungan terhadap perusahaan selalu ditanamkan. Perusahaan "diciptakan" seolah sebagai "bapak" yang dapat mengatur dan memenuhi kebutuhan warga.

Dalam usaha untuk mengetahui permainan kuasa pada relasi antara masyarakat dan perusahaan, Abrams (1998) menawarkan untuk mengurai satu persatu praktik-praktik pemberdayaan yang dilakukan oleh pihak yang dianggap dominan. Bahkan, Abrams mensinyalir bahwa semua kebaikan yang diberikan pada dasarnya untuk memenuhi dan kepentingan perusahaan (Abrams, 1988). Hal itu dapat mengurai permainan kuasa dan dominasi untuk meraih keuntungan untuk perusahaanbukan untuk rakyat seperti yang selama ini dibangun dan diimajinasikan oleh perusahaan.

Pada perspektif lain, relasi perusahaan dengan masyarakat melalui pendataan demografi, wilayah, dan membangun imajinasi perusahaan adalah dasar-dasar dari pembentukan negara (Migdal, 2001; Gupta, 1995). Dalam konteks ini, imajinasi tersebut adalah persepsi masyarakat terhadap perusahaan yang menempatkannya sebagai pusat dari aktivitas masyarakat. Padahal image diperoleh melalui dominasi, integrasi, kontrol, dan lain sebagainya. Sementara itu, praktik itu sendiri adalah dinamika sosial ketika ada akomodasi dari perusahaan ke masyarakat dan juga sebaliknya serta adanya kontestasi antara aktor dan agen di dalam perusahaan dan di masyarakat, misalnya tentang ladang dan juga kemitraan masyarakat terutama dalam hal mendapatkan bantuan.

Dalam perspektif masyarakat, perusahaan adalah pihak yang membantu dan memudahkan kehidupan mereka. Masyarakat tidak berpikir bahwa apa yang dilakukan oleh perusahaan adalah untuk kepentingan perusahaan itu sendiri, bukan untuk kepentingan masyarakat. Imaginasi masyarakat tentang perusahaan seringkali digunakan oleh perusahaan ketika diketahui ada masyarakat yang mencoba menggugat atau melakukan aktivitas yang dianggap mengganggu perusahaan, seperti penambangan. Dengan imaginasi yang demikian, perusahaan menempatkan dirinya sebagai pelindung dan masyarakat adalah yang dilindungi. Ketika pelindung mengalami masalah, maka masyarakat yang biasanya dilindungi akan membantu.

\section{Konsesi, Pelestarian Alam, dan Kontrol Sumber Daya}

Pada beberapa tahun belakangan, persoalan relasi antara perusahaan dan masyarakat mengalami gejolak, terutama dengan maraknya aktivitas penambangan emas oleh warga di lokasi perusahaan. Sebenarnya, penamaan lokasi konsesi adalah bentukan dari perusahaan, karena sebelum perusahaan itu ada, masyarakat telah lama bermukim. Penambangan emas ini merupkan kegiatan yang ilegal secara aturan negara dan perusahaan, karena tidak memiliki perizinan. Namun, menurut persepsi masyarakat, kegiatan penambangan ini adalah aktivitas legal karena dilakukan di ladang atau sungai.

Kategori legal dan ilegal adalah diskursus yang terus dinegosiasikan dalam relasi antara masyarakat dan perusahaan. Hanya karena area tersebut diklaim oleh perusahaan masuk dalam wilayah konsesinya, maka aktivitas tersebut dianggap ilegal. Namun, negosiasi wacana legal dan ilegal ini tidak mencegah masyarakat dalam menambang emas di lahan konsesi. Tiap hari ada penambahan warga yang menambang dan mulai merambah lahan-lahan lainnya. Kondisi ini tentu mengkhawatirkan karena beberapa wilayah dianggap sebagai wilayah area produksi perusahaan.

Lahan bekas tambang, selain rusak secara ekosistem juga tidak bisa ditanami ulang dengan tanaman-tanaman yang bernilai ekonomi. Untuk beberapa waktu, perusahaan tidak bisa berbuat banyak. Mandor sebagai "garda depan" pun tidak berdaya. Isu pemotongan bantuan atau tidak diberikan fasilitas lainnya tidak cukup ampuh meredam aktivitas penambangan tersebut. Hasil dari menambang yang diperoleh sudah cukup besar sehingga penambang tidak lagi membutuhkan berbagai bantuan dari perusahaan.

Perusahaan juga tidak bisa memberi tindakan secara langsung karena dikhawatirkan masyarakat akan berbuat nekat yang kemudian bisa memicu konflik yang lebih luas. Jika hal tersebut terjadi, dapat dipastikan akan mengganggu operasional perusahaan yang lebih luas. Hal yang bisa dilakukan oleh perusahaan adalah 
membangun wacana lain, yakni batas wilayah dan pelestarian lingkungan. Pihak perusahaan selalu mendorong wacana tersebut bergulir di masyarakat; ada yang sadar dan ada yang tidak. Dalam operasionalisasi wacana tersebut, perusahaan tidak menggunakan mandor secara langsung tetapi memberdayakan masyarakat yang sudah sadar dan menganggap bahwa aktivitas penambangan adalah merusak lingkungan.

Untuk mendukung wacana ini, perusahaan memberikan hasil-hasil penelitian dari lembaga di dalam negeri maupun luar negeri mengenai dampak buruk dari kerusakan lingkungan secara umum, seperti pemanasan global dan dampak langsung pertambangan. Selain itu, kesaksian dari orang-orang tua tentang kondisi lingkungan yang alami ikut mempengaruhi dan mendukung wacana yang dikembangkan oleh perusahaan. Bukti-bukti fisik seperti air sungai yang menjadi keruh, dangkal, dan kerusakan-kerusakan lainnya dapat menyakinkan masyarakat untuk sesaat menjauhi penambangan. Dalam konteks ini, masyarakat berhadapan dengan masyarakat.

Wacana konsesi yang sebelumnya didengungkan oleh perusahaan mulai dilupakan. Padahal sebelumnya masyarakat selalu "dicecoki" oleh wacana area konsesi perusahaan. Area konsesi ini selain memang memiliki kekuatan legal formal dari negara juga dijadikan "senjata" dalam mengontrol masyarakat untuk membuka lahan baru. Karena melalui menyebaran wacana konsesi ini, masyarakat terhegemoni oleh wacana perusahaan. Wacana yang dikembangkan oleh masyarakat, seperti batas lahan yang dimiliki oleh suatu desa sepanjang $5 \mathrm{~km}$ dari pusat desa, tidak begitu kuat mengemuka. Padahal, batas 5 km tersebut merupakan kesepakatan suku Dayak secara umum berdasarkan pertemuan besar seluruh elemen Dayak pada tahun 1920an (Ilon, 1990). Gugatan masyarakat tentang batas wilayah 5 $\mathrm{km}$ dari pusat desa tidak dihiraukan oleh perusahaan. Dalam kontestasi di atas, batas wilayah yang dimaksud oleh perusahaan adalah wilayah konsesi, bukan wilayah yang menjadi gugatan kepemilikan lahan oleh warga.

Wacana lainnya yang dihembuskan oleh perusahaan terkait dengan pertambangan emas yang dilakukan oleh masyarakat adalah penjagaan terhadap situs keramat alami yang diyakini oleh masyarakat sebagai tempat yang penting. Di tempat ini, memori kolektif masyarakat di simpan, upacara tradisi biasa digelar, dan berbagai keperluan masyarakat terhadap tradisi didapatkan. Di tempat ini perusahaan tidak menebang sama sekali, sedangkan di bekas ladang atau bekas pemukiman hanya kayu-kayu tertentu saja yang diambil. Pelusso (1993) secara jeli melihat adanya penyimpangan dan pemaksaan perusahaan dalam konservasi. Dalam kasus ini pun bisa dilihat bagaimana peta dan batas-batas wilayah operasional perusahaan memberikan "kesepakatan" tertentu dengan asumsi bahwa perusahaan mempunyai kapasitas, legitimasi, dan kewenangan yang akan mengatur semua sumber dalam batas teritori perusahaan tersebut. Implikasinya adalah bahwa perusahaan akan dapat mengontrol tingkah laku dari semua pengguna lokasi sumber dalam wilayah operasi mereka; apa pun sebab dari klaim perusahaan, apapun kompetisi alam untuk sumber itu, dan apapun alam atau keaslian resistensi untuk sumber kontrol perusahaan.

Selain itu, Peluso (1993) dalam salah satu artikelnya yang berjudul "Coercing Conservation: The Politics of State Resources Control" juga memaparkan bagaimana proses "kekerasan", baik fisik maupun nonfisik, yang dijalankan oleh aktor negara dan aktor nonnegara untuk menegakkan fungsi negara dalam mengontrol sumber daya. Peluso menjelaskan bagaimana di balik program konservasi yang diluncurkan oleh negara terdapat kepentingan untuk mengontrol akses terhadap sumber daya, terutama sumber daya kehutanan. Dalam mendukung argumentasinya, Peluso membuat dua asumsi. Pertama, kepentingan "negara" terkait dengan penyediaan ideologi, legitimasi, dan teknologi konservasi dimaksudkan sebagai upaya kontrol terhadap sumber daya alam. Kedua, program yang didukung kelompok konservasi internasional menghasilkan pencabutan hak milik masyarakat lokal atas klaim sumber daya.

Pembuatan peta dan wacana perusakan lingkungan serta area konsesi membatasi gerak masyarakat lokal dalam melakukan penambangan emas, walaupun aktivitas tersebut dilakukan di tanah yang secara tradisi sebagai tanah miliknya. Masyarakat takut menghadapi perusahaan ketika melakukan aktivitas tersebut, apalagi jika sampai tertangkap tangan, walaupun perusahaan sebenarnya juga mengetahui adanya aktivitas tersebut. Apa yang dilakukan oleh perusahaan, pada dasarnya adalah topeng yang penuh selubung dalam rangka menutupi kepentingan perusahaan itu sendiri. 


\section{Antara Masyarakat, Negara dan Swasta: Penutup}

Ada beberapa program-program yang disusun oleh SBK, sebagai induk dari PMDH, dalam memfasilitasi kepentingan-kepentingan masyarakat. Program-program tersebut misalnya penyediaan bibit, pupuk, sampai pada infrastruktur lainnya telah menciptakan ketergantungan masyarakat pada perusahaan. Selain itu, program-program tersebut juga menjadi ruang bagi perusahaan untuk mengontrol masyarakat. Tujuannya, supaya aktivitas masyarakat tidak mengganggu sistem produksi perusahaan yang telah lama disusun. Dua kepentingan ini membuat relasi diantara kedua pihak berdasarkan azas mutualisme atau saling membutuhkan. Masyarakat membutuhkan perusahaan untuk memenuhi kebutuhannya dan perusahaan membutuhkan masyarakat untuk tenaga kerja dan kelancaran produksi.

Dalam relasi antara masyarakat dan perusahaan, negara belum berperan sebagaimana layaknya. Bahkan, negara seringkali hadir bukan untuk menyelesaikan sengketa atau menfasilitasi kepentingan kedua belah pihak. Kehadiran negara bahkan justru untuk kepentingannya, yakni klaim atas program-program yang telah dilaksanakan oleh perusahaan.

Dalam menjalankan program di masyarakat selalu terjadi benturan antara menjaga kepentingan perusahaan pada satu sisi dan memberdayakan masyarakat sisi lainnya. Dalam usahanya menjaga kepentingan perusahaan, praktik-praktik yang dilakukan oleh perusahaan adalah melalui program-program yang diarahkan untuk memenuhi kebutuhan masyarakat secara langsung, seperti bantuan, perekrutan sebagai karyawan harian, serta pengadaan fasilitas transportasi. Program-program yang diadakan pun tidak secara sungguh-sungguh dilakukan, karena sejatinya itu hanyalah bentuk pengalihan terhadap kepentingan perusahaan. Tanpa adanya program, masyarakat akan menanyakan atau menggugat praktik-praktik yang dilakukan oleh perusahaan.

Dalam konteks ini, penanaman karet adalah salah satu hal yang menarik. Sebagain masyarakat berinisitif menanam karet di kebun, sebagai usaha yang dulu pernah dilakukan oleh orang tuanya dan melihat keuntungan sekarang. Masyarakatpun mendesak SBK supaya dapat memfasilitasi keinginan masyarakat dengan penyediaan bibit yang baik. Namun, ketika bibit tersedia, masyarakat justru mengambil bibit dari tetangga atau keluarga. Sampai saat ini, perkebunan karet yang digagas oleh masyarakat belum memperlihatkan hasil - belum terlihat masyarakat yang menjual getah karet.

Hubungan antara masyarakat dan SBK adalah hubungan yang saling menguntungkan dan saling bergantung. Satu sama lain saling memanfaatkan. Dalam relasi seperti ini, kehadiran negara dalam pengertian yang sebenarnya justru ditolak. Penolakan tersebut karena dapat mengganggu relasi yang sudah lama terjalin. Contoh kasus adalah adanya keinginan dari pemerintah desa dan kecamatan untuk mengelola dana pemberdayaan yang dikeluarkan oleh SBK untuk masyarakat. Masyarakat menolak usulan tersebut. Dalam anggapan masyarakat, jika dana sudah dikelola oleh negara maka tidak pernah menjadi barang dan dirasakan oleh masyarakat.

Berperannya perusahaan Sari Bumi Kusuma (SBK) sebagai "negara", terutama dalam memberikan pelayanan pendidikan dan kesehatan bagi masyarakat karena negara lambat bergerak, sedangkan kebutuhan masyarakat sudah mendesak. Salah satu contohnya adalah bangunan sekolah yang sudah rusak dan ketiadaan tenaga pengajar. Negara lama merespon kondisi ini, sedangkan kebutuhan pendidikan harus terpenuhi. Hal lainnya adalah infrastruktur bangunan maupun jalan. Antara pengajuan dan realisasi sangat lama. Kondisi-kondisi ini membuat masyarakat beralih ke SBK yang merespon dengan cepat berbagai kebutuhan masyarakat. Sebagai usaha memperkuat posisi masyarakat dalam interaksi dengan perusahaan, untuk itu, kehadiran negara yang sesungguhnya sangat diperlukan, apalagi beberapa kawasan konsesi milik perusahaan berstatus hutan adat.

\section{Daftar Pustaka}

Abrams, Philip. (1988). "Notes on the Difficulty of Studying the State". Journal of Historical Sociology Vol. 1 No. 1.

Anderson, Benedict. (1991). Imagined Communities: Reflections on the Origin and Spread of Nationalism. Verso. London.

Barr, C. (2002). Desentralization of Forest administration in Indonesia: Implication for forest sustainability, community livelihood and economic development. Cifor, Bogor.

Contreas-Hermosila, A \& Fay, C. (2005). Strengthening forest management in Indonesia through land tenure reform: issues and framework for action. Forest 
Trends and World Agroforestry Centre (ICRAF), Indonesia.

Corrigan, Philip. (1994). "State Formation", in Joseph, Gilbert, M dan Daniel Nugent. (eds.). Everyday Forms of State Formation: Revolution and the Negotiation of Rule in Mexico. Duke University Press. Durham and London.

Dove, Michael R. (1988). Sistem Perladangan di Indonesia: Studi kasus di Kalimantan Barat, Yogyakarta: Gajahmada University Press.

Edmunds, D. dan Eva Wollenberg, E. (2003). Local forest management: the impact of devolution policies. Earthscan Publications, London.

Eilenberg, Michael. (2012). At the Edges of States: Dynamics of state Formation in the Indonesian borderlands. KITLV Press. Leiden.

Ellen, R. (2002). "Pengetahuan tentang hutan, transformasi hutan: Ketidakpastian politik, sejarah ekologi, dan renegosiasi terhadap alam di Seram Tengah" dalam Li, Tania Murray (peny). 2002. Proses Transformasi Daerah Pedalaman di Indonesia. Yayasan Obor Indonesia, Jakarta.

Ferguson, J dan Akhil Gupta. (2002). "Spatializing states: Toward an Ethnography of Neoliberal Governmentality" American Ethnologist 29 (4): 981-1002. American Anthropological Association.

Foucault, Michel, (1995). Discipline and Punish: the Birth of the Prison. Vintage, New York.

Ghee, Lim Teck \& Gomes, Alberto G (peny). (1993). Suku Asli dan Pembangunan di Asia Tenggara. Yayasan Obor Indonesia, Jakarta.

Gupta, A. (1995). "Blurred Boundaries: The Discourse of Corruption, the Culture of Politics, and the Imagined State". American Ethnologist 22 (2): 375-402. American Anthropological Association.

Hansen, Thomas Blom dan Stepputat, Finn (ed). (2001). State of Imagination: Ethnographic Explorations of the Postcolonial State. Duke University Press. Durham and London.
Ilon, Nathan, Y. (1990). Ilustrasi dan Perwujudan Lambang Batang Garing dalam Dandang Tingang; Sebuah Konsepsi Memanusiakan Manusia dalam Filsafat Suku Dayak Ngaju, Kalimantan Tengah. TT. Proyek Bantuan Pembinaan Kebudayaan Daerah Tingkat I Kalimantan Tengah.

Ishikawa, Noburu. (2012). Between Frontier. Nation and Identity in a Southeast Asian Borderland. NUS Singapore dan NIAS Press.

Joseph, Gilbert, M dan Daniel Nugent. (1994). Everyday Forms of State Formation: Revolution and the Negotiation of Rule in Mexico. Duke University Press. Durham and London.

Kelly, J, D., dan Martha Kaplan. (2003). Nation and Decolonization: Toward a new anthropology of nationalism. Anthropological Theory Vol. 1(4): 419-437. SAGE Publications London, housand Oaks, CA and New Delhi.

Li, Tania Murray (ed.). (2002). Proses Transformasi Daerah Pedalaman di Indonesia. Yayasan Obor Indonesia, Jakarta.

Li, Tania Murray. (2012). The Will to Improve: Perencanaan, Kekuasaan, dan Pembangunan di Indonesia. Marjin Kiri. Jakarta. Penerjemah Hery Santoso, Pujo Semedi dari judul asli The will to improve: governmentality, development, and the practice of politics. Duke University Press.

Marin-Burgos, V., Acces, Power, and Justice in Commodity Frontiers; The Political Ecology of Access to Land and Palm Oil Expansion in Colombia; The Netherlands, University of Twente, Enschede.

Maring, Prudensius. (2010). Bagaimana Kekuasaan Bekerja di Balik Konflik, Perlawanan, dan Kolaborasi: Sebuah Sudut Pandang Antropologi Tentang Perebutan Sumber daya Ekologi. Lembaga Pengkajian Antropologi Kekuasaan Indonesia. Bekasi.

Marzali, Amri, (2002). Hukum Adat dan Komersialisasi Hutan di Luar Pulau Jawa Pada Masa Orde Baru. dalam Endang Suhendar (Penyunting). Menuju Keadilan Agraria: 70 Tahun Gunawan Wiradi. Akatiga. Bandung. 
Migdal, Joel S. (2001). State in Society: Studying How States and Societies Transform and Constitute One Another. Cambridge University Press.

Mitchell, Timothy. (1991). "The Limits of the State: Beyond Statist Approaches and Their Critics". The American Political Science Review, Vol. 85, No. 1. (Mar., 1991), pp.77-96.

Parker, Lyn. (2003). From Subjects to Citizens: Baliness Vilagers in the Indonesian Nation State. Leifsgade: NIAS Press.

Peluso, Nancy Lee. 1993. Coercing Conservation?: The Politics of State Resource Control. Publisher, Butterworth-Heinemann.

Peluso, Nancy Lee. (1998). "Legal Pluralism and Legacies of 'Customary Right' in Indonesia and Malaysian Borneo." Dalam Common Property Resources Digest 47:10-13.

Peluso, Nancy Lee. (2006). Hutan Kaya, Rakyat Melarat: Penguasaan Sumber Daya dan Perlawanan Rakyat. Yogyakarta: Insist Press.

Pembinaan Masyarakat Desa Hutan. (2009). Identifikasi Hak dan Kawasan Tradisional Masyarakat Desa Tanjung Paku di IUPHHK PT. Sari Bumi Kusuma Kalimantan Tengah. Report PMDH, The Nature Conservancy, Fauna Flora International.

Pembinaan Masyarakat Desa Hutan. (2009). Identifikasi Hak dan Kawasan Tradisional Masyarakat Desa Riam Batang di IUPHHK PT. Sari Bumi Kusuma Kalimantan Tengah. Report PMDH, The Nature Conservancy, Fauna Flora International.

Roseberry, William. (1994). Hegemony and The Language of Contention, (in) Joseph, Gilbert, M dan Daniel Nugent (eds.). Everyday Forms of State Formation: Revolution and the Negotiation of Rule in Mexico. Duke University Press. Durham and London.

Sayer, Derek. (1994). Everyday Forms of State Formation: Some Dissudent Remarks on "Hegemony. Ini Joseph, Gilbert, M dan Daniel Nugent. (eds.). Everyday Forms of State Formation: Revolution and the
Negotiation of Rule in Mexico. Duke University Press. Durham and London.

Scoot, James C. (1998). Seeing Like A State: How certain Schemes to Improve the Human Have Failed. Yale University Press.

Soedjito, H. (1995). Masyarakat Dayak: Perladangan dan Pelestarian Plasma Nutfah. Prosiding Seminar dan Lokakarya Nasional Etnobotani II: 330-341. 24-25 Januari 1995. Puslitbang Biologi-LIPI, Fak. Biologi UGM, Ikatan Pustakawan Indonesia. Yogyakarta.

Tipa, Gail \& Welch, Richard. (2006). "Comanagement of Natural Resources: Issues of Definition From an Indegenous Perspective". The Journal of Applaied Behavioral Science, Vol. 42 No. 3 pp 373-391.

Trouillot, Michel-Rolph. (2001). "The Anthropology of the State in the Age of Globalization: Close Encounters of the Deceptive Kind". Current Anthropology Volume 42, Number 1.

Wolf, Eric Robert. (1982). Europe and People Without History. Universitas of California Press.

\section{Internet}

http://www.saribumikusuma.net/index.php?optio $\mathrm{n}=\mathrm{com} \_$content\&view $=$article \&id=46:se jarah $\&$ catid $=35:$ sejarah $\&$ Itemid $=53$. Dia kses hari rabu, 18 Januari 2017, pukul 11.45 .

http://www.saribumikusuma.com/index.php?opti on $=$ com_content\&view $=$ article $\& i d=60$ \&Itemid $\overline{-}=78$ diakses haru Jum'at, 13 Oktober 2017, pukul 10:00. 
